\title{
Causes of equine abortion, stillbirth, and perinatal mortality in Brazil*
}

\section{Causas de abortamento, natimortalidade e mortalidade em equinos no Brasil}

\author{
Aline Aparecida da Silva' (1) (https://orcid.org/0000-0002-2270-6851) \\ Eliana Monteforte Cassaro Villalobos ${ }^{2}$ (D) (https://orcid.org/0000-0002-1965-2426) \\ Elenice Maria Sequetin Cunha2 (D) (https://orcid.org/0000-0002-8843-289X) \\ Maria do Carmo Custódio de Souza Hunold Lara² (D) (https://orcid.org/0000-0002-9705-6865) \\ Alessandra Figueiredo de Castro Nassar ${ }^{3}$ (D) (https://orcid.org/0000-0001-7490-9186) \\ Rosa Maria Piatti ${ }^{4}$ (D) (https://orcid.org/0000-0002-2497-5713) \\ Vanessa Castro 4 (D) (https://orcid.org/0000-0001-9225-0573) \\ Eliana Scarcelli Pinheiro4 (i) (https://orcid.org/0000-0003-4142-6983) \\ Aline Feola de Carvalho4 (D) (https://orcid.org/0000-0002-6643-2936) \\ Claudia Del Fava1** (D) (https://orcid.org/0000-0003-2967-0203)
}

\begin{abstract}
Abortion and complications in reproduction are important causes of economic loss in horse breeding. Studies of its causal agents can help to identify the primary pathogens or other factors involved and define appropriate measures to reduce its occurrence. This research aimed to investigate the primary causes of equine abortion, stillbirth, and perinatal mortality in regions of Brazil. Tissue from aborted fetuses, stillbirths, neonates and foals submitted to the Biological Institute of São Paulo, Brazil, from January 2010 to July 2013 were processed for viral and bacterial isolation, polymerase chain reaction (PCR), histology, and immunohistochemistry. Bacterial infection was the primary detected cause of abortion, found in 16 of the 53 animals submitted for bacterial analysis followed by viruses analysis in 2 of 105 animals, and noninfectious causes (neonatal isoerythrolysis) in 2 of 105 animals. Fungi were found in a single sample of 53 tested. The most frequent bacteria recovered were Escherichia coli, Enterobacter aerogenes, combined E. coli and Streptococcus spp., Staphylococcus spp., and Bacillus spp. The following agents were each observed in a single sample: Arcanobacterium pyogenes, Streptococcus spp., Corynebacterium spp., Actinobacillus spp., and Rhodococcus equi. The predominant identification of fecal and other opportunistic bacteria as opposed to pathogens commonly associated with equine abortion, such as Leptospira spp. and equine herpesvirus type 1 (EHV-1), suggests the need of improving hygiene management of breeding mares to prevent bacterial infection that may cause fetal loss, stillbirth, and perinatal mortality.
\end{abstract}

KEYWORDS: Equus caballus; infectious diseases; reproduction.
RESUMO: Abortamento e complicações na reprodução são importantes causas de perda econômica na equideocultura. Estudos dos agentes causais podem ajudar a identificar patógenos ou outros fatores envolvidos e definir medidas apropriadas para reduzir sua ocorrência. Esta pesquisa investigou as causas primárias de aborto, natimortalidade e mortalidade perinatal em equinos de diversas regiōes do Brasil. Tecidos de fetos abortados, natimortos e potros submetidos ao Instituto Biológico de São Paulo, Brasil, no período de janeiro de 2010 a julho de 2013, foram processados por meio de técnicas de isolamento viral e bacteriano, PCR, histologia e imuno-histoquímica. Infecção bacteriana foi a causa mais detectada, encontrada em 16 de 53 amostras submetidas à análise bacteriana, seguida de causa viral em 2 de 105 amostras, e causas não infecciosas (isoeritrólise neonatal) em 2 de 105 amostras. Fungo foi encontrado em uma única amostra de 53 testadas. As bactérias isoladas mais frequentemente foram Escherichia coli, Enterobacter aerogenes, E. coli associada a Streptococcus spp., Staphylococcus spp. associado a Bacillus spp. Os seguintes agentes foram observados em uma única amostra cada: Arcanobacterium pyogenes, Streptococcus spp., Corynebacterium spp., Actinobacillus spp. e Rhodococcus equi. A identificaçáo predominante de bactérias fecais e outras bactérias oportunistas, ao invés de outros patógenos comumente associados a quadros de abortamento equino, tais como Leptospira spp. e Herpesvírus equino tipo 1, sugere a necessidade de maior atenção no manejo higiênico das éguas em reproduçáo, a fim de prevenir infecçóes bacterianas que possam causar perda fetal, natimortalidade e mortalidade perinatal.

PALAVRAS CHAVES: Equus caballus, doenças infecciosas; reprodução.

\footnotetext{
*This article is part of the master's dissertation of the first author.

'Instituto Biológico - Centro de Pesquisa de Sanidade Animal - Laboratório de Anatomia Patológica - São Paulo (SP), Brazil.

${ }^{2}$ Instituto Biológico - Centro de Pesquisa de Sanidade Animal - Laboratório de Raiva e Encefalites - São Paulo (SP), Brazil.

${ }^{3}$ Instituto Biológico - Centro de Pesquisa de Sanidade Animal - Laboratório de Bacteriologia Geral - São Paulo (SP), Brazil.

${ }^{4}$ Instituto Biológico - Centro de Pesquisa de Sanidade Animal - Laboratório de Doenças Bacterianas da Reprodução - São Paulo (SP), Brazil.

**Corresponding author: claudia.fava@sp.gov.br

Received on: 03/04/2020. Accepted on: 08/02/2020
} 


\section{INTRODUCTION}

Abortion and complications of reproduction are important causes of economic losses in equine breeding due to the elevated costs incurred with diagnosis and treatment as well as the loss of animals (MOREIRA et al., 1998).

The causes of equine abortion, stillbirth, and perinatal mortality include bacterial agents Streptococcus spp., Staphylococcus spp., Escherichia coli, Leptospira spp., Rodococcus equi, and Klebsiella spp. (GENOVEZ et al., 1995; LAUGIER et al., 2011); viral agents as equid alphaherpesvirus 1 and equine viral arteritis (EVA) (MOREIRA et al., 1998; LAUGIER et al., 2011; HONG et al., 1993); and fungi Aspergillus spp., Candida albicans, Mucor spp., Zygomycetes spp., and Histoplasma capsulatum (HONG et al., 1993; SMITH et al., 2003; SZEREDI et al., 2008; JUFFO, 2016).

Birth of twins has been considerably reduced through detection with ultrasound scans, but other noninfectious causes including neonatal isoerythrolysis (an immune condition that leads to the lysis of blood cells after ingesting of antibodies present in colostrum), umbilical cord torsion, and umbilical cord/cervical pole ischemia disorder must be considered (HONG et al., 1993; SZEREDI et al., 2008; RICKETTS et al., 2001; RIZZONI; MIYAUCHI, 2012).

Studies of causes of abortion, stillbirth and perinatal mortality can help to identify the primary pathogens or other factors involved and define appropriate measures to reduce its occurrence. The most recent report from Brazil was conducted from January 2000 to June 2011 and presented data from a single region of the country (MARCOLONGO-PEREIRA et al., 2012). Further research is needed to expand available information. The goal of the present study was to determine the primary causes of equine abortion, stillbirth, and perinatal mortality in Brazil.

\section{MATERIAL AND METHODS}

\section{Sampled animals}

Convenience samples of Equus caballus were obtained from 37 fetuses (fetal loss before 300 days gestation), three stillbirths (death after 300 days), and perinatal deaths (death within seven days of birth), 21 foals under one month of age, and 44 fetuses of unknown age, from a total of 105 animals sent to the Biological Institute of São Paulo, from January 2010 to July 2013.

\section{Tissue samples}

Samples were submitted to the Pathological Anatomy Laboratory of the Biological Institute of São Paulo for differential diagnosis of abortion causes. Refrigerated tissues were subjected to virus isolation and polymerase chain reaction (PCR) performed at the Rabies and Encephalitis Laboratory and to bacteriological analysis by the General Bacteriology Laboratory and Reproductive Bacterial Diseases Laboratory. Tissue fragments were fixed in $10 \%$ buffered formalin for histology and immunohistochemistry (IHC) at the Pathological Anatomy Laboratory.

Tissue samples submitted to the laboratory or collected during laboratory necropsy included central nervous system (CNS) $(\mathrm{n}=44)$, lungs $(\mathrm{n}=83)$, heart $(\mathrm{n}=67)$, liver $(\mathrm{n}=82)$, kidney $(\mathrm{n}=86)$, spleen $(\mathrm{n}=74)$, thymus $(\mathrm{n}=26)$ stomach contents $(\mathrm{n}=23)$, placenta $(\mathrm{n}=40)$, and umbilical cord $(\mathrm{n}=16)$.

Histology was conducted according to standard protocols (PROPHET et al., 1995). Tissues were fixed in 10\% buffered formalin for $48 \mathrm{~h}$, transferred to $70 \%$ ethanol, dehydrated in an ethanol series, cleared in xylene, and embedded in paraffin. Sections were cut at $3 \mu \mathrm{m}$, deparaffinized, rehydrated, and stained with hematoxylin and eosin.

\section{Immunohistochemistry (IHC)}

Sections of lung and brain $(3 \mu \mathrm{m})$ for detection of equine herpesvirus type $1(\mathrm{EHV}-1)$ and of liver and kidney $(3 \mu \mathrm{m})$ for Leptospira spp. were dewaxed in xylene $30 \mathrm{~min}$ at $37^{\circ} \mathrm{C}$ followed by block of endogenous peroxidase in solution of $20 \mathrm{~mL}$ of $30 \%$ hydrogen peroxide diluted in $80 \mathrm{~mL}$ methanol for $30 \mathrm{~min}$. Antigen retrieval was performed with citrate buffer ( $\mathrm{pH}$ 6.0) by heating in a $1000 \mathrm{~W}$ microwave oven for $15 \mathrm{~min}$ prior to incubation with a 1:1000 dilution of goat antiserum (VMRD USA Inc. catalog 210-70-ERV, Pullman, Washington, USA) specific for ERV/EHV-1 (SILVA et al., 2018) and primary antibody to Leptospira serovar Canicola, strain LO4, titer 12:400 (FAINE, 1994). Sections were incubated with biotinylated secondary antibody (anti-mouse, -rabbit, and -goat immunoglobulin) (LSAB+ System -HRP, Dako ref. K0690 - Dako Cytomation, Carpinteria, California, USA) and exposure to 3,3'diaminobenzidinechromogen solution (DAB - Dako code ref K3468), counterstained with Mayer's hematoxylin, and mounted with Entellan (Merck) synthetic resin.

\section{Virus isolation}

One $\mathrm{mL}$ of $20 \%$ organ suspension [ $2 \mathrm{~g}$ of each organ tissue macerated with $8 \mathrm{~mL}$ Eagle's minimum essential medium (EMEM)] was inoculated into a monolayer culture of Vero cells at $37^{\circ} \mathrm{C}$ for $1 \mathrm{~h}$ (SILVA et al., 2018). At the end of the attachment period, cell monolayers were rinsed with $6 \mathrm{~mL}$ maintenance medium (EMEM containing $2 \%$ fetal calf serum supplemented with $200 \mathrm{U} / \mathrm{mL}$ penicillin, $200 \mathrm{mg} / \mathrm{mL}$ streptomycin, and $50 \mathrm{U} / \mathrm{mL}$ nystatin) and incubated at $37^{\circ} \mathrm{C}$. Three blind passages were conducted at seven-day intervals, and cells were assessed for herpesvirus cytopathic effect characterized by the presence of rounded, retractile cells, lysis, or syncytia formation. 


\section{Bacterial culture}

A pool of organ tissue from each animal $(\mathrm{n}=53)$ and 23 stomach contents were submitted to isolation and identification of aerobic (Enterobacteria and Gram-positive cocci) and microaerophilic bacteria (Campylobacter spp., Brucella spp., Leptospira spp., Listeria monocytogenes) (GENOVEZ et al., 1995; KIRKBRIDE, 1990; OIE, 2015). Microorganisms isolated in pure culture or predominating were considered potential causes of abortion (KIRKBRIDE, 1990).

Culture methods used for Leptospira spp. were EllinghausenMcCullough-Johnson-Harrismedium (Difco, USA) and Fletcher's medium with $15 \%$ sterile rabbit serum inactivated at $56^{\circ} \mathrm{C}$ for 30 min, enriched with $1 \% 5$-fluorouracil, 400 mg/L (Sigma, USA).

\section{Polymerase chain reaction (PCR)}

DNA was extracted using TRI Reagent according to the manufacturer's protocol. from $20 \%$ fetal organ suspensions (CHOMCZYNSKI, 1993). To detect EHV-1, primers that hybridize to the highly conserved $\mathrm{gB}$ gene regions inner primers (Invitrogen Brazil Ltd., São Paulo, Brazil) P1 forward 5'-CTTGTGAGATCTAACCGCAC-3'/P2 outer reverse 5'-GGGTATAGAGCTTTCATGGG-3' and P1/P3 inner reverse 5'-GCGTTATAGCTATCACGTCC-3' (MORI et al., 2009) were used.

Fragments of organs $(-2 \mathrm{~g})$ were macerated in a homogenizer (Stomacher 80) to obtain a pool of organ tissue from each animal, suspended in TE buffer $(10 \% \mathrm{w} / \mathrm{v})$, and stored at $-20^{\circ} \mathrm{C}$ until DNA extraction. Polymerase chain reaction to diagnose Leptospirosis employed primers specific to Leptospira spp. on a 331 bp fragment (Lep 1: 5 'GGCGGCGCGTCTTAAACA TG 3' and Lep 2: 3 'TTC CCCCCATTGAGCAAGATT 5').

\section{RESULTS}

Of the 105 animals examined, the cause of death could not be established in 84. Two showed a noninfectious cause (neonatal isoerythrolysis), and two were positive for EHV-1 by PCR. Tests for Leptospira spp. by isolation, PCR, or IHC were all negative. Bacteriological differentiation from Leptospira spp. was performed on 53 of the 105 samples, of which 16 were positive for other bacterial agents and one for yeast (Table 1).
Bacteria isolated in pure or predominant culture were E. coli (4/53), Enterobacter aerogenes (3/53), mixed E. coli and Streptococcus spp. (2/53), mixed Staphylococcus spp. and Bacillus spp. (2/53), and a single instance each of Arcanobacterium pyogenes, Streptococcus spp., Corynebacterium spp., Actinobacillus spp., Rhodococcus equi, and an unspecified yeast (Table 2).

In the 17 horses that tested positive for bacteria and fungi of the 53 examined, the main pathological lesions were white pulp hyperplasia in 12 of 12 spleen samples; lymphoid hyperplasia in 6 of 7 thymus samples; nonpurulent meningoencephalitis in 6 of 7 of CNS samples; nonpurulent pneumonia in 9 of 14 lung samples; nonpurulent glomerulonephritis in 7 of 12 kidney samples; nonpurulent hepatitis in 7 of 15 liver samples and nonpurulent myocarditis in 5 of 54 cardiac tissue samples; 84 animals were negative bacteria and fungi analysis also but presented predominant splenic white pulp hyperplasia in 58 of 64 spleen samples; thymic lymphoid hyperplasia in 15 of 19 thymus samples; nonpurulent meningoencephalitis in 23 of 37 CNS samples; nephrosis in 41 of 74 kidney samples; nonpurulent hepatitis in 29 of 67 liver samples; nonpurulent pleuropneumonia in 25 of 70 lung samples; and nonpurulent myocarditis in 5 of 54 heart samples $9.3 \%(5 / 54)$.

Table 2. Bacteria species, plus a single yeast, isolated from 53 horse guts from aborted fetuses, and perinatal mortalities.

\begin{tabular}{lr|}
\hline Isolated agent & $\begin{array}{c}\text { Horses } \\
\mathbf{n}(\%)\end{array}$ \\
\hline Escherichia coli & $4(7.5)$ \\
\hline E. coli + Streptococcus spp. & $2(3.8)$ \\
\hline Enterobacter aerogenes & $3(5.7)$ \\
\hline Staphylococcus spp. + Bacillus spp. & $2(3.8)$ \\
\hline Actinobacillus spp. & $1(1.9)$ \\
\hline Arcanobacterium pyogenes & $1(1.9)$ \\
\hline Corynebacterium spp. & $1(1.9)$ \\
\hline Rhodococcus equi & $1(1.9)$ \\
\hline Streptococcus spp. & $1(1.9)$ \\
\hline Yeast fungus & $1(1.9)$ \\
\hline Negative samples & $36(67.9)$ \\
\hline Total & 53 \\
\hline
\end{tabular}

Table 1. Cause or causal agent classification of equine abortion, stillbirth, and perinatal mortality.

\begin{tabular}{lccr} 
Cause of abortion/ perinatal death & Cases $(\mathbf{n})$ & Samples analyzed $(\mathbf{n})$ & \multicolumn{2}{c}{ Frequency (\%) } \\
\hline Noninfectious (neonatal isoerythrolysis) & 2 & 105 & 1.9 \\
\hline Viral infection (EHV-1) & 2 & 105 & 1.9 \\
\hline Bacterial infection & 16 & 53 & 30.2 \\
\hline Fungal infection & 1 & 53 & 1.9 \\
\hline No diagnosis & 84 & 105 & 80.0 \\
\hline
\end{tabular}


Forty percent of the analyzed samples did not have the time of abortion or death reported on the submission form, including the two EHV-1 positive samples. Of the animals positive for bacterial infections, the abortions occurred most frequently at 4-6 months gestation followed by 6-9 months. Two stillborn showed a noninfectious cause (neonatal isoerythrolysis) (Table 3). One of the two fetuses positive for EHV-1 was from São Paulo State and the source of the other was not provided. Among fetuses positive for bacteria, the highest number came from the states of São Paulo and Paraná with seven each (Table 4).

\section{DISCUSSION}

Of the 105 aborted fetuses, stillbirths and perinatal deaths submitted for differential diagnosis of causes of abortion or perinatal mortality, 53 were submitted to bacteriological analysis with 16 found positive for bacterial agents representing $30.0 \%$ of those tested. Other studies point to bacterial infections as the cause of $20-34 \%$ of equine infectious abortions, representing an important economic loss (MOREIRA et al., 1998; GENOVEZ et al., 1995; LAUGIER et al., 2011; MARCOLONGOPEREIRA et al., 2012). In the present study, the predominant agents isolated were $E$. coli in 4 of the 16 positive samples, $E$. aerogenes (3/16); E. coli + Streptococcus spp. (2/16); Staphylococcus spp. + Bacillus spp. (2/16).

In Brazil in the 1990s, equine bacterial abortion was predominantly associated with beta-hemolytic Streptococcus spp., E. coli, R. equi, S. aureus, and Staphylococcus spp. (MOREIRA et al., 1998; GENOVEZ et al., 1995). Other bacteria such as Salmonella spp., L. monocytogenes, and Klebsiella oxytoca were also isolated at lower frequency (GENOVEZ et al., 1995). The most recent published data in southern Rio

Table 3. Cause of death data on 105 aborted horse fetuses, stillbirths, and perinatal mortalities by age.

\begin{tabular}{|c|c|c|c|c|c|}
\hline Gestation age & $\begin{array}{c}\text { Viruses } \\
\text { n (\%) }\end{array}$ & $\begin{array}{c}\text { Bacteria } \\
\text { n (\%) }\end{array}$ & $\begin{array}{l}\text { Fungi } \\
\mathrm{n}(\%)\end{array}$ & $\begin{array}{c}\text { Noninfectious disease } \\
\mathrm{n}(\%)\end{array}$ & $\begin{array}{c}\text { Undiagnosed } \\
\text { n (\%) }\end{array}$ \\
\hline Fetus $1-3$ months & 0 & 0 & 0 & 0 & $6(5.7)$ \\
\hline Fetus $4-6$ months & 0 & $7(6.6 \%)$ & 0 & 0 & $3(2.8)$ \\
\hline Fetus $7-9$ months & 0 & $3(2.8 \%)$ & 0 & 0 & $11(10.4)$ \\
\hline Fetus $>9$ months & 0 & $3(2.8 \%)$ & 0 & 0 & $4(3.8)$ \\
\hline Stillbirth & 0 & 0 & 0 & $2(1.9)$ & $1(0.9)$ \\
\hline Month old foal & 0 & $1(0.9)$ & 0 & 0 & $20(19.0)$ \\
\hline Not available & $2(1.9)$ & $3(2.8)$ & $1(0.9)$ & 0 & $38(36.1)$ \\
\hline Sub-total & $2(1.9)$ & $17(16.1)$ & $1(0.9)$ & $2(1.9)$ & $83(79.0)$ \\
\hline Total & & & & 105 & \\
\hline
\end{tabular}

Table 4. Aborted horse fetuses, stillbirths, and perinatal mortalities classified by state of origin.

\begin{tabular}{|c|c|c|c|c|}
\hline State of origin & $\begin{array}{l}\text { Viruses } \\
\text { (\%) }\end{array}$ & $\begin{array}{l}\text { Bacteria } \\
\text { n (\%) }\end{array}$ & $\begin{array}{c}\text { Noninfectious causes* } \\
\text { n (\%) }\end{array}$ & $\begin{array}{c}\text { Undiagnosed } \\
\text { n (\%) }\end{array}$ \\
\hline Minas Gerais & 0 & 0 & 0 & $8(7.6)$ \\
\hline Distrito Federal & 0 & $1(0.9)$ & 0 & 0 \\
\hline Mato Grosso do Sul & 0 & 0 & $1(0.9)$ & $1(0.9)$ \\
\hline Pará & 0 & 0 & 0 & $1(0.9)$ \\
\hline Sergipe & 0 & 0 & 0 & $1(0.9)$ \\
\hline Tocantins & 0 & 0 & 0 & $1(0.9)$ \\
\hline Paraná & 0 & $7(6.6)$ & 0 & $10(9.5)$ \\
\hline Rio Grande do Sul & 0 & $1(0.9)$ & 0 & $2(1.9)$ \\
\hline Santa Catarina & 0 & 0 & 0 & $1(0.9)$ \\
\hline Rio de Janeiro & 0 & 0 & 0 & $9(8.5)$ \\
\hline São Paulo & $1(0.9)$ & $7(6.6)$ & 0 & $44(41.9)$ \\
\hline Not informed & $1(0.9)$ & $1(0.9)$ & $1(0.9)$ & $6(5.7)$ \\
\hline Subtotal & $2(1.9)$ & $17(16.1)$ & 2 (1.9) & $84(80.1)$ \\
\hline Total & & 105 & & \\
\hline
\end{tabular}


Grande do Sul reported beta-hemolytic Streptococcus, Klebisiella pneumoniae, E. coli and Streptococcus spp. to be predominant (MARCOLONGO-PEREIRA et al., 2012).

In the USA, studies of causes of equine abortion, stillbirth, perinatal mortality, and placentitis have predominantly shown isolation of Streptococcus equi subspecies zooepidemicus, E. coli, and alpha- and beta-hemolytic Streptococcus (HONG et al., 1993; TENGELSEN et al., 1997). Other agents including Actinobacillus equuli, Serratia marcescens, R. equi, S. equi, S. equisimilis, Campylobacter spp., Corynebacterium spp., Klebsiella, Micrococcus, S. aureus, and Staphylococcus xylosus have also been isolated (TENGELSEN et al., 1997).

Similarly, in the United Kingdom, Hungary, France, and Italy, E. coli; Streptococcus spp., mainly beta-hemolytic and zooepidemicus; and Staphylococcus spp. were the most common bacteria isolated with Klebsiella pneumoniae, E. aerogenes and Chlamydophila psittaci also mentioned (LAUGIER et al., 2011; SMITH et al., 2003; SZEREDI et al., 2008; MARENZONI et al., 2012). In Japan, in 2007-2008, S. equi subsp. zooepidemicus were the most frequently isolated bacteria (29.5\%), followed by E. coli (20.5\%) and Salmonella abortus equi (MURASE et al., 2017).

LAUGIER et al. (2011) determined the bacterium responsible for equine abortion could be isolated from allantochorion and fetal organs, implying fetal septicemia leading to chronic placental insufficiency and extensive placental lesions, which can retard fetal development or result in emaciation and death of the fetus.

In the present study, none of the fetuses were positive for Leptospira spp. Low rates of Leptospira spp. as a cause of equine abortion or stillbirth death have been reported in Brazil: 1.88\% (2/106) (GENOVEZ et al., 1995) and 0.0\% (MOREIRA et al., 1998), with some evidence of higher rates: 5.6\% (4/72) (MARCOLONGO-PEREIRA et al., 2012) and 5.2\% (4/77) (JUFFO, 2016). Conversely, in an area of central Kentucky, USA, a peak of $15.7 \%$ of Leptospira spp. was reported by HONG et al. (1993) with serovars Pomona and Grippotyphosa predominating. Recent studies in other countries have revealed $0 \%$ to $1.9 \%$ (LAUGIER et al., 2011; RICKETTS et al., 2001; MARENZONI et al., 2012). Opportunistic fungi as cause of equine abortion are rare compared to bacteria (HONG et al., 1993; JUFFO, 2016; TENGELSEN et al., 1997). In the present study, a single yeast fungus, which could not be identified, was isolated from samples of liver and kidney of an aborted fetus. A similar rate (1/106) in Brazil was reported by GENOVEZ et al. (1995) with isolation of Candida spp. Other authors, in other countries report the isolation of Mucor spp. (1/77), Zygomycetes spp., and H. capsulatum (2/96) (SZEREDI et al., 2008; JUFFO, 2016; TENGELSEN et al., 1997). SMITH et al. (2003) reported fungal placentitis in 1.4\% (18/1252) of cases with isolation of Aspergillus and Absidia.

Equid alphaherpesvirus 1 is traditionally recognized as an important agent involved in equine abortion. Levels of EHV-1 abortion reported in the 1990s varied from 8.3 to
40\% (TENGELSEN et al., 1997; BAŻANÓW et al., 2014; SCHULTHEISS et al., 1993). More recent studies have pointed to lower rates of EHV-1: 6.9\% in France (LAUGIER et al., 2011), 6.5\% in the United Kingdom (SMITH et al., 2203), $16 \%$ in Hungary (SZEREDI et al., 2008), 10.1\% in Japan (MURASE et al., 2017) and 8.9\% in Germany (WEBER et al., 2018). A single study in Italy reported EHV-1 above 20\% (MARENZONI et al., 2012).

In Brazil, since the 1990s, a similar decrease has been reported in rates of abortion due to EHV-1: 8.0\% (3/50) (MOREIRA et al., 1998), 4.2\% (3/26) (MARCOLONGOPEREIRA et al., 2012), and 1.9\% (2/105) (SILVA et al., 2018). BROWN et al. (2007) reported low prevalence of EHV-1 infection even among a population of thoroughbreds in which the virus was known to be endemic and suggested the possibility that pregnant mares become infected without aborting; however, it is important to mention that EHV-1 occurs more frequently in the final third of pregnancy. In the present study, the number of abortions with a gestational age of 10 to 12 months was small, which may influence in the low occurrence observed.

A study covering 1977-2010 in Poland found rates of 25.6\% for EHV-1 (BAŻANÓW et al., 2014). The authors also report that the rates of isolation of the two viruses were inversely proportional, but most laboratories do not usually include them in routine differential diagnosis of equine abortion or foal death.

Two cases of death due to neonatal isoerythrolysis, an isoimmune-hemolytic anemia directly linked to the ingestion of milk were observed. The disease occurs when the maternal alloantibodies to the neonate blood are transferred to the foal via colostrum, causing lysis of red blood cells (RADOSTITS et al., 2002). No cases of umbilical cord torsion, dystocia, twinning, or other noninfectious cause were observed in the present study. In Brazil, MOREIRA et al. (1998) reported twinning (4.5\%) as the only cause of noninfectious abortion in their study. MARCOLONGO-PEREIRA et al. (2012) found $8.3 \%$ of abortions to be noninfectious and mentioned umbilical cord torsion (2.8\%), dystocia (1.4\%), noninfectious maternal disease (1.4\%), maternal-fetal incompatibility (1.4\%), and congenital malformation $(1.4 \%)$ as the main causes (MARCOLONGO-PEREIRA et al., 2012).

In the USA (TENGELSEN et al., 1997), United Kingdom (SMITH et al., 2003), France, (LAUGIER et al., 2011), and Japan (MURASE et al., 2017), high rates of noninfectious causes of abortion or stillbirth are reported. In the study of TENGELSEN et al. (1997), congenital defects including cranial and cervical spine and thoracic-lumbar deformities, as well as limb contractures accounted for $14.2 \%$ of congenital defects. SMITH et al. (2003), in the UK, reported high rates $(38.8 \%)$ of problems associated with umbilical cord torsion and umbilical cord/cervical pole ischemia disorder as the most common diagnosis in noninfectious abortion and neonatal. 
SMITH et al. (2003) also reported intrapartum stillbirth $(13.7 \%)$ and twinning $(6.0 \%)$.

LAUGIER et al. (2011), in France, reported 27.2\% noninfectious causes, with umbilical cord disorders responsible for $16.5 \%$ of the cases, followed by placental villous hypoplasia or atrophy (4.7\%), lethal congenital anomalies (1.9\%), and twinning (1.5\%). MURASE et al. (2017), in Japan, observed predominant noninfectious causes of abortion to be circulation failure (19.0\%), followed by multiple causes (3.1\%), deformity $(0.6 \%)$, placental abnormality $(0.6 \%)$, and other causes $(0.3 \%)$.

Deformities including diaphragm aplasia, head deformity, insufficient abdominal wall closure, diaphragmatic aplasia, Schistosomus reflexus, severely deformed kidney and liver, severe placental calcification, and trauma of the mare have also been reported at low rates (SZEREDI et al., 2008; MURASE et al., 2017; TENGELSEN et al., 1997). In equine abortion samples analyzed by TENGELSEN et al. (1997), $46.0 \%$ of the animals presented deficiency in vitamin E, $80.1 \%$ were deficient in selenium, and $56.3 \%$ were deficient in both. The influence of these types of deficiency should be investigated as a noninfectious cause of equine abortion and stillbirth, since little research in the area has been published. In the present study, $80.0 \%$ of abortions showed no conclusive diagnosis.

Other authors have reported rates of uncertain diagnosis ranging from 25.1 to $47.2 \%$ (LAUGIER et al., 2011; SZEREDI et al., 2008; MARCOLONGO-PEREIRA et al., 2012), but SMITH et al. (2003) reported only $7.7 \%$ undetermined diagnosis. Often, uncertainty is likely due to advanced states of autolysis of the fetus or to fetuses submitted without associated membranes (LAUGIER et al., 2011; SMITH et al., 2003). Extensive autolysis was observed in samples of kidney, liver, and central nervous system. Nearly half of the studied samples were not submitted to bacteriological analysis since it was not requested by the owner/professional, which may have contributed to the high number of inconclusive cases.

Current literature confirms that fetal death can occur as a result of action of a microorganism on the fetus, as well as due to the influence of toxins and changes in fetal circulation via acute infectious processes generated by pathogens acting on the pregnant female (maternal septicemia). It is imperative for accurate determination cause of abortion that serological samples from the mother, placenta, umbilical cord, and vaginal or uterine discharge after delivery be examined, but this material is often not submitted to the laboratories (GENOVEZ et al., 1995; LAUGIER et al., 2011; SMITH et al., 2003; SZEREDI et al., 2008).

In practice animals sent to laboratories for necropsy often arrive after unfavorable storage conditions making diagnosis by conventional techniques a challenge. In addition, the clinical-epidemiological records are often incomplete. In the present study, age information was not available for most part of the samples. Current literature reports $85.4-94.3 \%$ of abortions to occur at 6-9 months of gestation, but earlier abortions may be underestimated because of difficulty in finding small fetuses in pasture and the possibility of their consumption by carnivores (LAUGIER et al., 2011; HONG et al., 1993; SMITH et al., 2003; MARCOLONGO-PEREIRA et al., 2012; SILVA et al., 2018; MURASE et al., 2017; TENGELSEN et al., 1997). Following recommended procedures in collection and transport of samples to the laboratory and the adequate filling of clinical-epidemiological records are imperative to the effectiveness of the differential diagnosis (OIE, 2015; PITUCO et al., 2010).

The main lesions in the animals with no diagnosis were in the lymphoid organs, splenic white pulp hyperplasia, thymic lymphoid hyperplasia, and in the central nervous system, nonpurulent meningoencephalitis, suggesting a neurotropic infectious agent. The most frequent pathology seen in kidney of samples positive for bacterial agents was nonpurulent glomerulonephritis, while in the negative bacteriological samples, no diagnosis concluded and the two cases positive for EHV-1, the predominant kidney lesion was nephrosis. Other studies of bacterial infection have reported predominant purulent suppurative and pyogranulomatous pneumonia or hepatitis and did not observe changes in kidney (LAUGIER et al., 2011; SZEREDI et al., 2008; JUFFO, 2016).

LAUGIER et al. (2011) reported 27 cases of abortion, including 24 with placentitis, in which macroscopic and/or histologic lesions observed were suggestive of an infectious origin but no specific pathogenic agent was isolated. In contrast, SZEREDI et al. (2008) and MARCOLONGO-PEREIRA et al. (2014) observed only $2 \%$ of cases with inflammatory lesions to have no identified agent. Described lesions were mild to moderate pneumonia, mild serous hepatitis, and nonpurulent nephritis. The low frequency of occurrence of EHV-1 and absence of Leptospira spp. can be attributed to antibodies due to natural infection and/or to the increased practice of systematic vaccination for these diseases in recent years, conferring maternal immunity (MARCOLONGOPEREIRA et al., 2014; CARVALHO et al., 2000). Analysis of maternal blood serum together with the fetus and placenta is important to confirm this hypothesis, but serum of the mare is seldom referred for serodiagnosis (SILVA et al., 2018; BROWN et al., 2007).

To increase accurate detection of causes of abortion and perinatal mortality, it is also important to include in routine investigation other agents that have frequently been cited as causes of equine abortion, such as EHV-2 -4 and -5 equine infectious anemia, EVA, and Chlamydia (LAUGIER et al., 2011; SMITH et al., 2003; BROWN et al., 2007; SZEREDI et al., 2008; MARENZONI et al., 2012; BAŻANÓW et al., 2014; WEBER et al., 2018). Protozoan infections such as Babesia equi, Encephalitozoon cuniculi, Neospora spp., and Toxoplasma gondii are also often not considered causes of abortion, which may lead to inaccurate diagnosis of the cause of decreased birth rate in farm animals (SZEREDI et al., 2008; MARCOLONGO-PEREIRA et al., 2012). 
Pasteurella pneumotropica and toxic plants such as Ateleia glazioviana are less commonly cited causes of equine abortion and placentitis and must be better researched (JUFFO, 2016, MARCOLONGO-PEREIRA et al., 2014).

The most frequently identified causes of abortion, stillborn, and perinatal mortality are still opportunistic bacteria often isolated from the gastrointestinal and genitourinary tract of mares and the environment (MOREIRA et al., 1998; GENOVEZ et al., 1995; JUFFO, 2016; MARCOLONGOPEREIRA et al., 2012). The structure of the mare genital tract makes females more susceptible to infection, defects of conformation of vulva, loss of muscle mass of the perineum, as well as displacement of the anal sphincter anteriorly during estrus may increase this susceptibility (GRÜNERT et al., 2005). Despite improvements in environmental and nutritional management in horse rearing, the relative percentage of enterobacteria and Gram-positive cocci can indicate the need to reinforce hygiene measures in the management of pregnant mares, including maintaining the environment and facilities, as well as sanitation of utensils and systematic vaccination, to prevent fetal loss and perinatal mortality (MOREIRA et al., 1998). The high number of samples with no conclusive diagnosis highlights the need for greater care in submitting laboratory samples and the need to investigate causes of equine abortion in addition to those routinely researched.

\section{CONCLUSION}

The predominant identification of fecal and other opportunistic bacteria suggests the need of improving hygiene management of breeding mares to prevent bacterial infection that may cause fetal loss, stillbirth, and perinatal mortality, but more studies, which include a larger number of samples and pathogens not commonly investigated, are needed to support this theory.

ACKNOWLEDGEMENTS: Not applicable.

FUNDING: This study was financed in part by the Coordenação de Aperfeiçoamento de Pessoal de Nível Superior - Brasil (CAPES) Finance Code 001 and the Fundação de Amparo à Pesquisa do Estado de São Paulo (Grant: 2009/13864-8, 2012/00277-0).

CONFLICTS OF INTEREST: All authors declare that they have no conflict of interest.

ETHICAL APPROVAL: This study was approved by Ethics Committee on Animal Experiments of Biological Institute under protocol number 106/10.

AVAILABILITY OF DATA AND MATERIAL: All data generated or analyzed during this study are included in this published article.

AUTHORS' CONTRIBUTIONS: Conceptualization: Silva, A.A.; Del Fava, C. Formal analysis: Silva, A.A.; Villalobos, E.M.C.; Cunha, E.M.S.; Lara, M.C.C.S.; Nassar, A.F.C.; Piatti, R.M.; Castro, V.; Pinheiro, E.S.; Carvalho, A.F.; Del Fava, C. Funding acquisition: Del Fava, C. Investigation: Silva, A.A.; Villalobos, E.M.C.; Cunha, E.M.S.; Lara, M.C.C.S.; Nassar, A.F.C.; Piatti, R.M.; Pinheiro, E.S.; Carvalho, A.F.; Del Fava, C. Methodology: Silva, A.A.; Villalobos, E.M.C.; Cunha, E.M.S.; Lara, M.C.C.S.; Nassar, A.F.C.; Piatti, R.M.; V.; Pinheiro, E.S.; Carvalho, A.F.; Del Fava, C. Project administration: Del Fava, C. Writing original draft: Silva, A.A.; Del Fava, C. Writing - review \& editing: Del Fava, C.

| | | | | | | | | | | | | | | | | | | | | | | | | | | | | | | | | | | | | | | | | | | | | | | | | | | | | | | | | | | | | | | | | | | | | | | | | | | | | | | | | | | | | | | | | | | | | | | | | | | | | | | | | | | | | | | | | | | | | | | | | | | | | | | | | | | | | | | | | | | | | | | | | | | | | | | | | | | | | | | | | | | | | | | | | | | | | | | | | | | | | | | | | | | | | | | | | | | | | | | | | | | | | | | | | | | | | | REFERENCES

BAŻANÓW, B.A.; FRĄCKA, A.B.; JACKULAK, N.A.;STARONIEWICZ, Z.M.; PLOCH, S.M. A 34-year retrospective study of equine viral abortion in Poland. Polish Journal of Veterinary Science, Warszawa, v. 1 7, n.4, p.607-612, 2014. https://doi.org/10.2478/pjvs-2014-0091

BROWN, J.A.; MAPES, S.; BALL, B.A.; HODDER, A.D.J.; LIU, I.K.M.; PUSTERLA, N. Prevalence of equine herpesvirus- 1 infection among thoroughbreds residing on a farm on which the virus was endemic. Journal of the American Veterinary Medical Association, Schaumburg, v.231, n.4, p.577-580, 2007. https:// doi.org/10.2460/javma.231.4.577
CARVALHO, R.; OLIVEIRA, A.M.; SOUZA, A.M.; PASSOS, L.M.F.; MARTINS, A.S. Prevalence of equine herpesvirus type 1 latency detected by polymerase chain reaction. Archives of Virology, Vienna, v.145, n.9, p.1773-1787, 2000. https://doi.org/10.1007/ s007050070055

CHOMCZYNSKI, P. A reagent for the single-step simultaneous isolation of RNA, DNA and proteins from cell and tissue samples. Biotechniques, London, v.15, n.3, p.532-537, 1993. Available from: https://europepmc.org/article/med/7692896. Access on: 3 May 2016. 
FAINE, S. Leptospira and leptospirosis. Boca Raton: CRC Press, 1994. 353p.

GENOVEZ, M.E.; SCARCELLI, E.; TORRES, A.P.; CARRASCO, S.; CARDOSO, M.V.; SOUZA, C.A.I.; MACRUZ, R. Isolamentos bacterianos de fetos equinos abortados examinados no Instituto Biológico, no período de 1985 a 1995. Arquivos do Instituto Biológico, São Paulo, v.62, n.1-2, p.21-24, 1995. Available from: http://www.sidalc.net/cgi-bin/wxis.exe/?lsisScript=AGB.xis\&me thod $=$ post $\&$ formato $=2 \&$ cantidad $=1$ \&expresion $=m f n=196017$. Access on: 3 May 2016.

GRÜNERT, E.; BIRGEL, E.H.; VALE, W.G. Patologia e clínica da reprodução dos animais mamíferos domésticos: ginecologia. São Paulo: Varela, 2005. 551p.

HONG, C.B.; DONAHUE, J.M.; GILES JUNIOR, R.C.; PETRITESMURPHY, M.B.; POONACHA, K.B.; ROBERTS, A.W.; SMITH, B.J.; TRAMONTIN, R.R.; TUTLE, P.A.; SWERCZEK, T.W. Equine abortion and stillbirth in central Kentucky during 1988 and 1989 foaling seasons. Journal of Veterinary Diagnostic Investigation, Guelph, v.5, n.4, p.560-566. 1993. https://doi. org/10.1177/104063879300500410

JUFFO, G.D. Causas de aborto, natimortalidade e morte perinatal em equinos diagnosticadas no setor de Patologia Veterinária da UFRGS de 2000 a 2015. 2016. Thesis (Doctorate in Veterinary Sciences) - Universidade Federal do Rio Grade do Sul, Porto Alegre, 2016. Available from: https://www.lume.ufrgs.br/ handle/10183/153240. Access on: 5 July 2019.

KIRKBRIDE, C.A. Laboratory diagnosis of livestock abortion. Ames: lowa State University Press, 1990. 260p.

LAUGIER, C.; FOUCHER, N.; SEVIN, C.; LEON, A.; TAPPREST, J. A 24-year retrospective study of equine abortion in Normandy (France). Journal of Equine Veterinary Science, Lexington, v.3 1, n.3, p.116-123, 201 1. https://doi.org/10.1016/j.jevs.2010.12.012

MARCOLONGO-PEREIRA, C.; ADRIEN, M.L.; LADEIRA, S.R.L.; SOARES, M.P.; ASSIS-BRASIL, N.D.; SCHILD, A.L. Abortos em equinos na região Sul do Rio Grande do Sul: estudo de 72 casos. Pesquisa Veterinária Brasileira, Rio de Janeiro, v.32, n.1, p.22-26, 2012 . https://doi.org/10.1590/ So $100-736 \times 2012000100005$

MARCOLONGO-PEREIRA, C.; ESTIMA-SILVA, P.; SOARES, M.P.; SALLIS, E.S.V.; GRECCO, F.B.; RAFFI, M.B.; FERNANDES, C.G.; SCHILD, A.L. Doenças de equinos na região Sul do Rio Grande do Sul. Pesquisa Veterinária Brasileira, Rio de Janeiro v.34, n.3, p.205-210, 2014. https://doi.org/10.1590/ so100-736X2014000300002

MARENZONI, M.L.; LEPRI, E.; PROIETTI, P.C.; BIETTA, A.; COLETTI, M.; TIMONEY, P.J.; PASSAMONTI, F. Causes of equine abortion, stillbirth and neonatal death in central Italy. Veterinary Record, London, v.170, n.10, 262, 2012. https://doi.org/10.1136/ vr. 100551

MOREIRA, N., KRÜGER, E.R., WARTH, J.F.G, BIESDORF, S.M., GOULARTE, M.M.M., WEISS, R.R. Aspectos etiológicos e epidemiológicos do aborto eqüino. Archives of Veterinary Science, Cabral, v.3, n.1, p.25-30, 1998. https://doi.org/10.5380/avs. v3i1.3735
MORI, E.; MORI, C.M.C.; MASSIRONI, S.M.G.; CUNHA, E.M.S.; VILLALOBOS, E.M.C.; LARA, M.C.C.S.H.; FERNANDES, W.R. Detection of equid herpesvirus 1 DNA by polymerase chain reaction after experimental inoculation of horses with a Brazilian A4/72 strain. Brazilian Journal of Veterinary Research and Animal Science, São Paulo, v.46, n.4, p.256-261, 2009. https://doi.org/10.11606/ issn. 1678-4456.bjvras.2009.26773

MURASE, H.; MIYAZAWA, M.; HARADA, T.; OZAWA, M.; SATO, F.; HADA, T. Aborted fetal sizes of thoroughbred horses in Hidaka, Japan, between 2005 and 2015. Journal of Equine Science, Tokyo, v.28, n.2, p.47-53, 2017. https://doi.org/10.1294/jes.28.47

OIE World Organisation for Animal Health. Equine rhinopneumonitis. In: Manual of diagnostic tests and vaccines for terrestrial animals. Paris: OIE, 2015. Chap.2.5.9. Available from: https://www.oie. int/fileadmin/Home/eng/Health_standards/tahm/2.05.09_ EQUINE_RHINO.pdf. Access on: 29 May 2015

PITUCO, E.M.; DEL FAVA, C.; RIBEIRO, C.P.; BERSANO, J.G.; MIYASHIRO, S. Ruminantes, equídeos, suídeos. In: Brasil. Ministério da Pecuária e Agricultura; Organização PanAmericana da Saúde. Manual veterinário de colheita e envio de amostras: manual técnico. Cooperação Técnica MAPA/ OPAS PANAFTOSA Saúde Animal do Brasil. Rio de Janeiro: PANAFTOSA/OPAS/OMS, 2010. chap.2, p.35-143. Available from: https://iris.paho.org/handle/10665.2/33893. Access on: 5 Jun. 2017.

PROPHET, E.B.; MILLS, B.; ARRINGTON, J.; SOBIN, L.H. Manual de métodos histotecnológicos del Instituto de Patología de las Fuerzas Armadas de los Estados Unidos de América. Washington: Registro de Patología, 1995. 280p.

RADOSTITS, O.M.; GAY, C.C.; BLOOD, D.C.; HINCHCLIFF, K.W. Clínica Veterinária: um tratado de doenças dos bovinos, ovinos, suínos, caprinos e eqüinos. Rio de Janeiro: Guanabara Koogan, 2002. $1737 p$.

RICKETTS, S.W.; BARRELET, A.; WHITWELL, K.E. A review of the causes of abortion in UK mares and means of diagnosis used in an equine studfarm practice in Newmarket. Pferdeheilkunde, Germany, v.17, n.6, p.589-592, 2001. https://doi.org/10.21836/ PEM20010610

RIZZONI, L.B.; MIYAUCHI, T.A. Principais doenças dos neonatos equinos. Acta Veterinaria Brasilica, Mossoró, v.6, n.1, p.9-16, 2012. Available from: https://periodicos.ufersa.edu.br/index. php/acta/article/view/2694. Access on: 4 May 2017.

SCHULTHEISS, P.C.; COLLINS, J.K.; CARMAN, J. Use of an immunoperoxidase technique to detect equine herpesvirus- 1 antigen in formalin-fixed paraffin-embedded equine fetal tissues. Journal of Veterinary Diagnostic Investigation, Guelph, v.5, n.1, p.12-15, 1993. https://doi. org/10.1177/104063879300500104

SILVA, A.A.; CUNHA, E.M.S.; LARA, M.C.C.S.H.; VILLALOBOS, E.M.C.; NASSAR, A.F.C.; MORI, E.; ZANUZZI, C.N.; GALOSI, C.M.; DEL FAVA, C. Low occurrence of equine herpesvirus 1 (EHV-1) as cause of abortion and perinatal mortality in Brazil. Arquivos do Instituto Biológico, São Paulo, v.85, e0852017, 2018. https:// doi.org/10.1590/1808-1657000852017 
SMITH, K.C.; BLUNDEN, A.S.; WHITWELL, K.E.; DUNN, K.A.; WALES, A.D. A survey of equine abortion, stillbirth and neonatal death in the UK from 1988 to 1997. Equine Veterinary Journal, Cambridgeshire, v.35, n.5, p.496-501, 2003. https://doi. org/10.2746/042516403775600578

SZEREDI, L.; TENK, M.; JÁNOSI, S.; PÁLFI, V.; HOTZEL, H.; SACHSE, K.; POSPISCHIL, A.; BOZSÓ, M.; GLÁVITS, R.; MOLNÁR, T. A survey of equine abortion and perinatal foal losses in Hungary during a three-year period (1998-2000). Acta Veterinaria Hungarica, Budapest, v.56, n.3, p.353-367, 2008. https://doi.org/10.1556/avet.56.2008.3.9
TENGELSEN, L.A. et al. A 12-year retrospective study of equine abortion in Michigan. Journal of Veterinary Diagnostic Investigation, Guelph, v.9, n..3, p.303-306, 1997. https://doi. org/10.1177/104063879700900312

WEBER, R.; HOSPES, R.; WEHREND, A. Causes of abortion in horses - overview of the literature and own evaluations. Tierarztl Prax Ausg G Grosstiere Nutztiere, Gießen, v.46, n.1, p.35-42, 2018. Available from: https://www.thieme-connect. de/products/ejournals/abstract/10.15653/TPG-170517. Access on: 3 Mar. 2019. 